\title{
Cybercrime as an Impact of Communication Technology Development
}

\author{
ARUADSU
}

\begin{abstract}
This article aims to analyse cybercrime in society as a model of crime that develops as the advancement of Internet technology. Cybercrime becomes a practice that will create community behaviour that is vulnerable to conflicts and legal issues. The approach used in this writing is literature research, with a data analysis technique in the form of content analysis with the aim of obtaining valid inference and can be re-examined based on its context. Individual actions within a community group are actions prescribed by norms, values, and social structures. The reality in this cybercrime as a simulation, i.e. the creation of unproposed real models or hyper-reality reality. Through the simulation model, humans are framed in one space, which is identified as real, even if it is a pseudo or mere imaginary that the emergence of cybercrime as human practice in public sphere is characterized as space without control, but on the other hand because without such control, so cybercrime becomes an anarchist space without rules and norms.
\end{abstract}

Keywords: cyber, crime, society, internet, cyberspace

\section{INTRODUCTION}

In societal life, we often encounter changes in all aspects of life, including changes in the community itself, because there is essentially no static society. There are always changes in society dynamically. Either the changes build up in the sense of positive impact in the future for the community or instead bring a bad impact to the community. The change is a technological innovation.

Technological advances are also advancing information. Information can be obtained from friends, family, print media and electronic media. Especially in today's modern era, many people are already using new media that is Internet media[1].

The use of the Internet is not a special thing or particular for certain circles, both in terms of profession, community, education and age. Almost all groups of people already know and are familiar with the Internet. Along with the development of time and the modernization of the Internet becomes a necessity and human activity as community members[2]. In addition to being a professional prosecution, professional development, scientific development, news, and entertainment, Internet is also an alternative way for someone to interact as a social creature. Internet presence makes it easy for people to make information and data that is not necessarily found directly in the print media that can be encountered daily. Especially because the obstacles are way and costs are not small[3].

In Indonesia, there can be internet cafes that scattered along the roadside. In addition, there are many public places, educational institutions, cafes, malls, and recreation venues that offer hotspot or Wi-Fi services to people who have laptops or notebooks. Besides, there are many types of mobile phones equipped with Internet applications.

Activities based on Internet technology, is now no longer a new thing in the information society. The Internet has even been used by children of preschool age, parents, businessmen, agencies, employees to housewives[4]. This interactive digital communication Media is able to connect information society quickly, easily and without knowing the boundaries of the region. Countries that control the Internet in the millennial era is ensured to be a developed country if the Internet is used wisely especially in the areas of research, education, administration, socialization, networking and business.

The Netter (Internet users) can quickly know the development of technological research in different parts of the world. With just a search engine-like Google, users around the world have easy Internet access to a variety of information[5]. Compared with books and libraries, the internet symbolizes decentralization, knowledge (knowledge) information and data is extreme. The development of Internet technology with its social network has formed a new society in virtual form. This community is another face of a real society called cyber society/Cyberspace/cyber community[6]. This form of society is in a virtual space, where there is no need for the physical presence of the members of the community. A space that no longer questioned the partition between nations, which into as a global village. Various social processes occur like making love, greeting, socializing, doing business, and learning[7]. The development of the Cyber society became a symbol of human civilization progress. With this technology, all human activity is facilitated.

In addition to providing benefits for human life, the impact of this invention also affects the dark side of human life. Social problems in the real world also penetrated into this virtual world. Evil Behaviors in cyber society commonly called cybercrime also celebrate the dynamics of life in them. If in the real world we know the action of criminal theft and robbery of the Bank, in the Cyber society we also find a case of similar criminality such as account breach through Internet Banking facilities.

Internet penetration is so large if it is not used wisely it will give birth to crimes in cyberspace or that is termed cybercrime. Cybercrime happened first in the United States in the 1960 's. Various Cybercrime cases that occurred then began from manipulating academic transcripts of students at Brooklyn College New York, the use of computers in narcotic smuggling, Employees ' misuse of computers to unauthorized access to the Pacific National Bank's Security Database, which resulted in a loss of US $\$ 10.2$ million in 1978[8]. 
Cybercrime is also happening in Indonesia, even this crime has actually existed since the Internet came into Indonesia. Internet users in Indonesia are only 14, 5 million people of the total population who reach 220 million. Although there are no 10 percent, Indonesia has been ranked first in cybercrimes. In 2007 Indonesia's position had decreased in position four after Ukraine and some eastern European countries booked more cybercrime rates. Due to the high crimes committed in Indonesia cyber world blacklisted among payment providers through the Internet (Internet payment)[9].

The rise of cybercrime that occurs within the cyber society, shows the symptoms of shifting the social problems of the real world[10]. The borderless, uncontrolled cyber-society nature of crime is difficult to track, and has become an ideal space for social issues to grow. This crime in his preview. Use advanced telematics technologies that are hard to see and can do anywhere. So the potential to grow social problems becomes difficult to stop.

\section{LITERATURE REVIEW}

A wide variety of understanding about cybercrime. But when viewed from the origin of the word, cybercrime consists of two words, namely' cyber' and' crime'. The word 'cyber' stands for' cyberspace', which derives from the word' cybernetics' and' space' he term cyberspace appeared first in 1984 in William Gibson's novel Neuromancer[11]. Whereas' crime 'means' evil: action That harm others', as does the Internet and cyberspace, so cybercrime can be interpreted as an act of criminality occurring in the virtual world or the criminality occurring on the internet that is often called (cybercrime) either attacking Public facilities in cyberspace or private ownership, whose main tool is to use the Internet[12].

Cybercrime is a form of criminal which uses both the Internet and the computer as a means of committing criminal acts. Problems related to this type of crime such as hacking, copyright infringement, child pornography, child exploitation, carding and still food crime by the way of the Internet. Also includes violations of privacy when confidential information is lost or stolen, and others.

Illegal access; Opening or signing in to another person's account without permission and is deliberately an act of crime in cyberspace. An account that has been compromised by the perpetrator is very likely to make the owner suffer losses[13]. Disseminating illegal content; Illegal content is content in which there is information or data that is unethical, untrue, or unlawful. There are many types of illegal content deployed on the Internet. However, the most frequently disseminated news is HOAX and also content that contains pornographic elements[14]. Hacking and Cracking; Piracy of the property rights of others. For example, account hijacking, website hijacking, virus spread, probing, and more. Data counterfeiting; is a cybercrime by falsifying data on important documents that are stored as script document on the Internet. One of the practices of this data counterfeiting for example falsification of documents on e-commerce sites created as if typo or mistyped occurs to benefit the culprit[15].

The methods in doing so are quite varied. Here are some of the frequent ways cybercrime works. Password Cracker; An act of stealing someone else's password by using a program that can unlock password encryption. Spoofing the act of faking the data or identity of a person so that hackers can login into a computer network like the original user[16]. Destructive Devices; this is a virus-containing program or software where the goal is to damage or destroy data in the victim's computer. Some of these programs include Worms, Trojan horses, Nukes, Email Bombs, etc.

\section{METHOD}

In this study, researchers used the approach of literature studies. The literature study is a study used to dull information and data with the help of various materials in libraries and the Internet such as documents, books, journals, magazines, historical stories[17]. Meanwhile, according to the literature study experts are theoretical studies, references and other scientific literature related to the culture, values and norms that develop in the social situation studied[18].

The data analysis technique used in this study is a method of content analysis. This analysis is used to obtain valid inference and can be researched based on its context[19]. In this analysis will be the process of selecting, comparing, combining and sorting various information and data until found the relevant[20].

\section{RESULT}

Along with the development of Internet technology, led to the emergence of crimes called "Cybercrime" or crimes through the Internet network. The emergence of some cases of "Cybercrime" in Indonesia, such as credit card theft, hacking some sites, intercepted transmission of other people's data, such as email, and manipulating data by setting up unwanted commands into the programmer Computer. Thus, in computer crimes it is possible to have both formyl and delic material. Proceeding formil is the act of someone who enters the computer of another person without permission, while proceeding material is an act that raises the consequences of harm to others[21]. Cybercrime has become a threat of stability, so the government is difficult to offset the crime techniques done with computer technology, especially Internet and intranet networks[22].

Here are 8 examples of Cyber Crime cases that ever happened with the mode and analysis of completion:

Case 1

In 1982 there has been a money evasion in the bank through a computer as reported "voice renewal" issue of January 10, 1991 about two students who broke the money from a private bank in Jakarta as much as Rp. 372,100,000.00 with Computer. The further development of computer technology is a computer network that then spawned a global communication and information room known as Internet. In such cases, this case is purely criminal, this type of crime usually uses the Internet only 
as a means of crime. Its completion, because this crime includes money evasion on the bank using the computer as a means of committing a crime. In accordance with the law in Indonesia, the person is threatened with section 362 of the criminal CODE (Book of Penal Law) or article 378 of the PENAL code, depending on the mode of action he does.

Case 2

This case is happening today and is talking a lot of people, the case of the pornographic video of Ariel "Peterpan" with Luna Maya and Cut dance, the video is uploaded on the Internet by a initials "RJ " and now the case is in the process. In such cases, the attack target mode is addressed to individuals or individuals who have specific traits or criteria as intended by the attack.

The completion of the case with the legal line, the uploader and the corresponding person in the video also dragged the following articles, article 29 UURI Nomor 44 Tahun 2008 on pornography article 56, with a penalty of at least 6 months to 12 years. Or with a minimum penalty of 250 million Idr to 6 billion Idr. And or article 282 paragraph 1 PENAL code.

Case 3

The term hacker usually refers to someone who has a great interest in learning the computer system in detail and how to improve its capabilities. As for those who often do action destruction on the internet are usually called crackers. Arguably this cracker is actually a hacker who utilizes his ability to negative things. Cracking activity on the internet has a very wide scope, from the hijacking of other people's accounts, website hijacking, probing, spreading viruses, to the target audience. The last action is referred to as DoS (Denial of Service). The Dos attack is an attack aimed at disabling targets (hangs, crashes) so that it cannot provide services. In the case of Hacking this is usually the mode of a hacker is to cheat or ruffled data so that the owner cannot access his web. For this case article 406 the criminal CODE may be imposed on the case of deface or hacking that makes the system belong to someone else, such as the website or the program becomes malfunctioning or can be used properly.

Case 4

Carding, one of the types of cybercrime that took place in Bandung around the year 2003. Carding is a crime that is done to steal other people's credit card numbers and be used in trading transactions on the Internet. The perpetrators who are mostly teenagers and students of this student, are torn down by police officers after several successful transactions on the Internet using another cardholder's credit card. The perpetrators, the average operating from Internet cafes scattered in the city of Bandung. They used to transact using the credit card numbers they acquired from some sites. But again, the police officers refused to mention the site that was used for reasons still in further investigation. This crime mode is theft, because the perpetrators use other people's credit cards to find the items they want on the goods auction site. Because of the crimes they do, they will be taken in violation of article 378 of the criminal CODE of fraud, article 363 on theft and article 263 on identity counterfeiting.

Case 5

Cybersquatting is registering, selling or using a domain name with the intent of taking advantage of a trademark or other person's name. Generally referring to the practice of buying a domain name using the names of existing businesses or names of people of a famous person with a view to selling names to profit for their business. An example of cybersquatting case, Carlos Slim, the richest man in the world was less signet in managing his brand on the internet, until his domain was dragged on others. Luckily the case could be classified cyber squat so that the domain carlosslim.com could be taken over. The model trades the popularity of the company and keyword Carlos Slim by selling Google ads to its competitors. Settlement of this case is to use the Anti cybersquatting procedure of the Consumer Protection Act (ACPA), entitles the trademark owner to prosecute a cyber squatter in the Federal Court and transfer the domain name back to the owner Trademark. In some cases, cyber squatter must pay a money indemnity.

\section{Discussion}

Every community in his social life must have had a social regularity system called values and norms. The system governs the continuity of the life of a society. Borrowing the term Durkheim, the system was formed due to collective awareness (collective consciousness), in which values and norms are social adhesives embraced and mutually agreed upon by members of the community[23]. Furthermore, according to Durkheim, individual actions in a community group are defined by norms, values, and social structures. In other words, Durkheim saw the public in a deterministic position. The social structure with rule gives signs to each community member in action and behavior. It is related to what is allowed and what is forbidden in social life of society.

Values and norms in society do not always run as they should. There is also the behavior of society that is felt not in accordance with the values and norms. This is what causes social problems. The social problem itself by Robert A. Nisbet, is defined as a matter pertaining to social and moral values. The problem is an issue because it concerns the behavior of immoral, contrary to law and is destructive[24]. Some of the most important social issues in Indonesia, which are categorized as a violation of the value and norms of one of them are the rise of Cyber Crime cases or crimes in cyberspace that are troubling society.

The development of human civilization seems to have reached the most leading point[25]. From the human civilization that is still primitive, to the development of modern society as digital as today. Information technology such as the Internet becomes a symbol of progress on modern society[26]. The Internet has penetrated the boundaries and the between the people of this hemisphere.

The Internet (interconnection-networking) is literally a global system of interconnected computer networks using the standard Internet Protocol Suite (TCP/IP) to serve billions of users around the world. While the Internet (The big 'I') is a common computer system, which relates globally and uses TCP/IP as packet switching communication protocol. The largest Internet network is called the Internet[27]. How to connect a series with this method is called internetworking. With this Internet network, we can connect with humans of any part of the world. We can connect with various kinds of social networks, such as Facebook, Twitter, e-mail, Skype, or Yahoo Messenger. Modern society in the digital era is facilitated with everything that is "E", e-banking (banking facilities), e-mail (electronic mail), E-confrence (meeting facilities), E-Files (archiving facilities), e-Office (Office activities Facilities), E-Fax (fax facility) 
etc.

The development of information technology has brought people, which were once limited by the territory to the global society without a partition, called globalization[28]. According to Robertson (1992), globalization refers to the intensive narrowing of the world and the increase in our awareness of the world, which is increasing global connections and our understanding of them. This narrowing of the world can be understood based on the institutions of modernity. While the intensification of world consciousness can be better perceived in the cultural viewpoint. Technological developments Information is not able to create a global community, but is materially able to develop a new life space for the community, so without realizing it, the human community has lived in two lives, namely the life of real society and Cyber community[29].

Cyber community or in this writing is referred to as the Cyber society is another side of human society life. Jean Baudrillard, referring to reality in this cyber society as a simulation, is the creation of unproposed real models or hyper-reality reality. Through the simulation model, humans are framed in a single space, which is considered real, even if it is a pseudo or a mere imaginary. Humans inhabit a space of reality[30], in which the difference between the real and the right fantasia and the fake is a different thin [31]. In the Cyber society, life progresses following the patterns of real society life. This form of life is not tangible to be seen through human sensing, but it can be felt and witnessed as a relative of life.

Community members in this cyber society usually use e-mail, website and provider as their home address. These cyber-society inhabitants are usually called. Netter (Internet user)[32]. Social processes and social interactions can take place intensely like making love, greeting, hanging out, doing business, learning or even stealing. Or just walk around like chatting and browsing or search. In the process of community interaction in the Cyber Society, the end also forms the subjective meaning between the members, and ultimately builds an intersubjective meaning of his world. The Cyber Society borrows the term Hebermas can be categorized as a public sphere, where the free netters are without domination.

Cyber Society as a public sphere emphasized by Moch Faisal, he said, cyber society or cyberspace is an anarchist-rational space where there is no foundation of norms and values. Each entity in it has their own norms and values. But behind its anarchal nature, the cyberspace has turned into a transnational public space, where the discourse without power relations, all actors can play[33].

Cyberspace is hard to control due to its beyond everything and its anarchic nature. It goes beyond anything (beyond everything), because it's detached from the three-dimensional social space we inhabit. It is anarchist, because it does not have shared norms and the same values to make it manageable.

The emergence of cyber society poses debate. On the one hand it is a public sphere characterized as space without control and without domination, but on the other hand because without such control, the Cyber Society becomes an anarchist space without rules and norms. So as it happens in real life man when in the condition of chaos (chaos without norms), in the Cyber society also emerged social problems.

These social problems are commonly referred to as cybercrime. This crime is done by modus operandi using advanced telematics technology. The crime of this model is done by using telematics technology procedures that are difficult to see with the naked eye, even difficult to be proved, except through scientific substantiation[34]. But analogous, crimes that are common in cyber community revolve around the crimes against fellow cyber-society members who are closely related to the positive laws and crimes against public morals. These crimes in the cyber society eventually became troubling social problems.

\section{CONCLUSION}

Examples of cases along with the above analysis resulted in the conclusion that the use of communication technology will impact the community, especially the negative impact of the emergence of a form of evil called Cyber Crime.

The emergence of some cases of "Cybercrime" in Indonesia, such as money-evasion in the bank through the computer, pornographic video cases uploaded on the internet, hackers, carding or crimes committed to steal credit card numbers belonging to others and used In trading transactions on the Internet, intentionally spreading the virus on the Internet, cybersquatting which is interpreted as registering, selling or using domain names with the intent of taking advantage of trademarks or other people's names through Internet and document theft cases state leaders through the Internet, all these cybercrime cases show the symptoms of shifting social problems from the real world. The borderless, uncontrolled cyber-society nature of crime is difficult to track, and has become an ideal space for social issues to grow. This crime in its preview uses advanced telematics technology that is difficult to see and can do anywhere. So the potential to grow social problems becomes difficult to stop.

Every community in his social life must have had a social regularity system called values and norms. The system governs the continuity of the life of a society. Values and norms in society do not always run as they should. There is also a community behaviour that is perceived as not in accordance with the values and norms. This is what causes social problems. Some of the most important social issues in Indonesia, which are categorized as a violation of the value and norms of one of them are the rise of Cyber Crime cases or crimes in cyberspace that are troubling society.

A sure development brings a big impact to the surroundings. It is unlikely that a change does not drag other related things. As with the development of communication and information, all components of both political, social, and economic are changing in line with the communication revolution. But we as a society must be clever in managing it so that it does not happen fatal.

\section{REFERENCES}

[1] M. C. B. Umanailo, Marginalisasi Buruh Tani Akibat Alih Fungsi Lahan, no. March 2016. 2016.

[2] A. D. E et al., "The Existence of Waranggana in Tayub Ritual," Int. J. Sci. Technol. Res., vol. 8, no. 10, 2019.

[3] N. S. Wisnujati et al., "Public Relations Management through Management by Objective," Int. J. Sci. Technol. Res., vol. 8, no. 10, 2019.

[4] A. Rahmat, A. D. Gs, N. Djafri, I. Shofwan, and M. C. B. Umanailo, "The Influence of Family Leadership towards Adolescent Social Values in the City of Gorontalo," Int. J. Sci. Technol. Res., vol. 8, no. 10, 2019. 

Student-Athletes," Int. J. Sci. Technol. Res., vol. 8, no. 10, 2019.

[6] W. Rumaolat, E. Dusra, I. S. Tunny, M. S. J. Malisngorar, S. Cahyawati, and M. C. B. Umanailo, "Relationship Diet and Regulate Blood Sugar in the Elderly with DM Type li in Waimital Village , Kairatu District, West Seram Regency," Int. J. Sci. Technol. Res., vol. 8, no. 10, 2019.

[7] I. Shofwan et al., "Non-Formal Learning Strategy Based on Tahfidz and Character in the Primary School," Int. J. Sci. Technol. Res., vol. 8, no. 10, 2019.

[8] M. Muhasidah et al., "Healthy Food with Children Learning Achievements at Makassar City Elementary School," Int. J. Sci. Technol. Res., vol. 8, no. 10, 2019.

[9] M. S. J. Malisngorar et al., "Effect of Health Education Knowledge about Antenatal Care Mothers against Hamlet Land Shake the District Huamual West Seram Regency," Int. J. Sci. Technol. Res., vol. 8, no. 10, 2019.

[10] S. Prafitriyani, I. Magfirah, N. F. Amir, A. Irmawati, and M. C. B. Umanailo, "Influence of Emotional Intelligence on Mathematics Learning Outcomes of Class VII Middle School 9 Buru Students," Int. J. Sci. Technol. Res., vol. 8, no. 10, 2019.

[11] M. Y. Zakaria, W. Malmia, A. Irmawati, N. F. Amir, and M. C. B. Umanailo, "Effect Mathematics Learning Achievement Motivation on Junior High School Students 1 Namlea," Int. J. Sci. Technol. Res., vol. 8, no. 10, 2019.

[12] M. Apriyanto and M. C. B. Umanailo, "Decrease Polyphenols, Ethanol , Lactic Acid , and Acetic Acid during Fermentation with Addition of Cocoa Beans Innoculum," Int. J. Sci. Technol. Res., vol. 8, no. 10, 2019.

[13] R. Djibu, I. Shofwan, and M. C. Basrun, "Development of Andragogical Learning Model to Improve Life Skill for Teenagers Who Drop Out of School in Gorontalo City," Int. J. Sci. Technol. Res., vol. 8, no. 10, 2019.

[14] M. Nawawi et al., "The Village Kalesang Program as a Poverty Alleviation Community," Int. J. Sci. Technol. Res., vol. 8, no. 10, 2019.

[15] A. Ervina, D. Zulmi, R. Ariesta, Y. Aridawarni, A. Aminah, and M. C. B. Umanailo, "The Relationship of Patterns Use of Time and Income Family with Juvenile Delinquency in Junior High School Students at Lebak Distric," Int. J. Sci. Technol. Res., vol. 8, no. 10, 2019.

[16] L. T. Muharlisiani et al., "The role of Customer Service through Customer Relationship Management ( CRM ) to Increase Customer Loyalty and Good Image," Int. J. Sci. Technol. Res., vol. 8, no. 10, 2019.

[17] B. S. Amanto, M. C. B. Umanailo, R. S. Wulandari, T. Taufik, and S. Susiati, "Local Consumption Diversification," Int. J. Sci. Technol. Res., vol. 8, no. 8, 2019.

[18] S. S. F. Assagaf et al., "Construction of the Village as a Development Shaft in the Island Buru," Int. J. Sci. Technol. Res., vol. 8, no. 9, 2019.

[19] A. Wael et al., "'Bupolo ' Motion Reading," Int. J. Sci. Technol. Res., vol. 8, no. 9, 2019.

[20] M. C. B. Umanailo, M. Yulisvestra, K. K. Oki, W. Mulyasari, and R. Ridwan, "The Thought of Emile Durkheim in the Contestation of Development in Indonesia," Int. J. Sci. Technol. Res., vol. 8, no. 8, 2019.

[21] H. Hamiru et al., "Eucalyptus Oil Workers," Int. J. Sci. Technol. Res., vol. 8, no. 9, 2019.

[22] R. Bugis et al., "Workers in the Namlea Market," Int. J. Sci. Technol. Res., vol. 8, no. 9, 2019.

[23] M. C. B. Umanailo et al., "Cybercrime Case as Impact Development of Communication Technology That Troubling Society," Int. J. Sci. Technol. Res., vol. 8, no. 9, 2019.

[24] A. L. Wabula, M. Musyawir, A. Irmawati, B. Rebel, D. M. Darajat, and M. C. B. Umanailo, "Maghrib Movement," Int. J. Sci. Technol. Res., vol. 8, no. 9, 2019.

[25] W. Malmia et al., "Problem-Based Learning as an Effort to Improve Student Learning Outcomes," Int. J. Sci. Technol. Res., vol. 8, no. 9, 2019.

[26] L. J. Buton et al., "The Effect of Nasa Liquid Organic Fertilizer Concentration and Planting Distance to Growth and Production of Beans," Int. J. Sci. Technol. Res., vol. 8, no. 9, 2019.

[27] M. C. B. Umanailo, "Kalesang Dorp in Context De Bouw van Village."

[28] M. C. B. Umanailo, "Overview Phenomenological Research," pp. 1-6.

[29] M. C. B. Umanailo et al., "Comprehension To Village," 2018, pp. 1-2.

[30] M. C. B. Umanailo, I. Hamid, M. Nawawi, S. Pulhehe, S. Yusuf, and A. T. Bon, "Utilization of Qualitative Methods in Research Universities," in Proceedings of the International Conference on Industrial Engineering and Operations Management, 2019, pp. $2076-2081$.

[31] M. C. B. Umanailo, N. Handayani, A. Masniati, S. H. Makatita, and S. Lisaholit, "The Urbanization and Diversification of Farmland Namlea Village," Int. J. Sci. Technol. Res., vol. 8, no. 8, pp. 1049-1053, 2019.

[32] M. C. B. Umanailo, "Integration of Community Empowerment Models [Pengintegrasian Model Pemberdayaan Masyarakat]," Proceeding Community Dev., vol. 2, p. 268, Mar. 2019.

[33] M. C. B. Umanailo, MARGINALISASI BURUH TANI AKIBAT ALIH FUNGSI LAHAN, 1st ed. Namlea: FAM PUBLISHING, 2016.

[34] M. C. B. Umanailo, ILMU SOSIAL BUDAYA DASAR, 1st ed. Namlea: FAM PUBLISHING, 2015. 